Rupantaran : A Multidisciplinary Journal

Vol. IV : pp 82-99, October, 2020

ISSN : 2091-0061

https://doi.org/10.3126/rupantaran.v4i1.34190

Research Management Cell (RMC)

Dhankuta Multiple Campus, Dhankuta

Tribhuvan University, Nepal

\title{
Teachers Understanding Towards COVID-19: A Case of Dhankuta Multiple Campus, Dhankuta, Nepal
}

Kewal Ram Parajuli ${ }^{1}$

Tika Ram Linkha

\section{Abstract}

Teacher educators are playing a significant role in managing pandemic situation at various ways. Their role is important to raise public awareness about epidemic and pandemic diseases, like COVID-19. It is mainly due to education and educators are to be considered as an initiator of changes at community level. Their preparedness, understanding, practices and participation can be reliable way to measure the impact of COVID-19 in Dhankuta district. In this context, the focus of this paper is to estimate teachers' knowledge, understanding and practices to preventive measures of COVID-19. In addition, the paper has also intended to analyze the opportunities and challenges that lockdown has bought in their academic environment. For this purpose, 51 teachers were chosen from Dhankuta Multiple Campus using proportionate stratified random sampling (SRS) method with covering gender and faculties. Web based cross sectional research design was applied and some of the variables, like knowledge about COVID-19, adoptive practices, challenges faced in academic environment and reduction strategy were considered to collect and analyze data. The findings of this paper indicate that the mean score of overall knowledge and practices are 6.90 and 6.4 respectively and $94.1 \%$ faces academic challenges. Meantime, the respondent reported that hotels and markets were more vulnerable places as compared to other economic sectors. Their responses ranked such as use of mask, sanitizer, distance maintain, lockdown, and quarantine were some of the ways to prevent COVID-19. However, $70.6 \%$ teachers were involved in online classes, e-library and continuing their academic activities. This paper concludes that the pandemic of COVID-19 has also created a new environment in teaching-learning with the application of ICT in pedagogy in changing situation.

Key Words: academic environments, COVID-19, pandemic, teachers understanding, teaching-learning

1. Mr. Parajuli is a Lecturer of Population Education at Dhankuta Multiple Campus, Dhankuta, T.U., Nepal.

2. Mr. Linkha is a Lecturer of Geography at Dhankuta Multiple Campus, Dhankuta, T.U., Nepal. Email: tika.linkha@gmail.com 


\section{Introduction}

Management of epidemics is influenced by the level of knowledge on particular pandemic and preventive practices which people have adopted. Educators can play a significant role in slow down the spread of pandemics through their knowledge generation, dissemination and sharing activities with students in community level. The attitude and behavior of students are highly influenced by teachers through teaching modes either by conventional, online or blended. Transmission of epidemic can be effectively controlled by adequate understanding of community (Rothman, 2012).

Timeline of Major Epidemics in the World

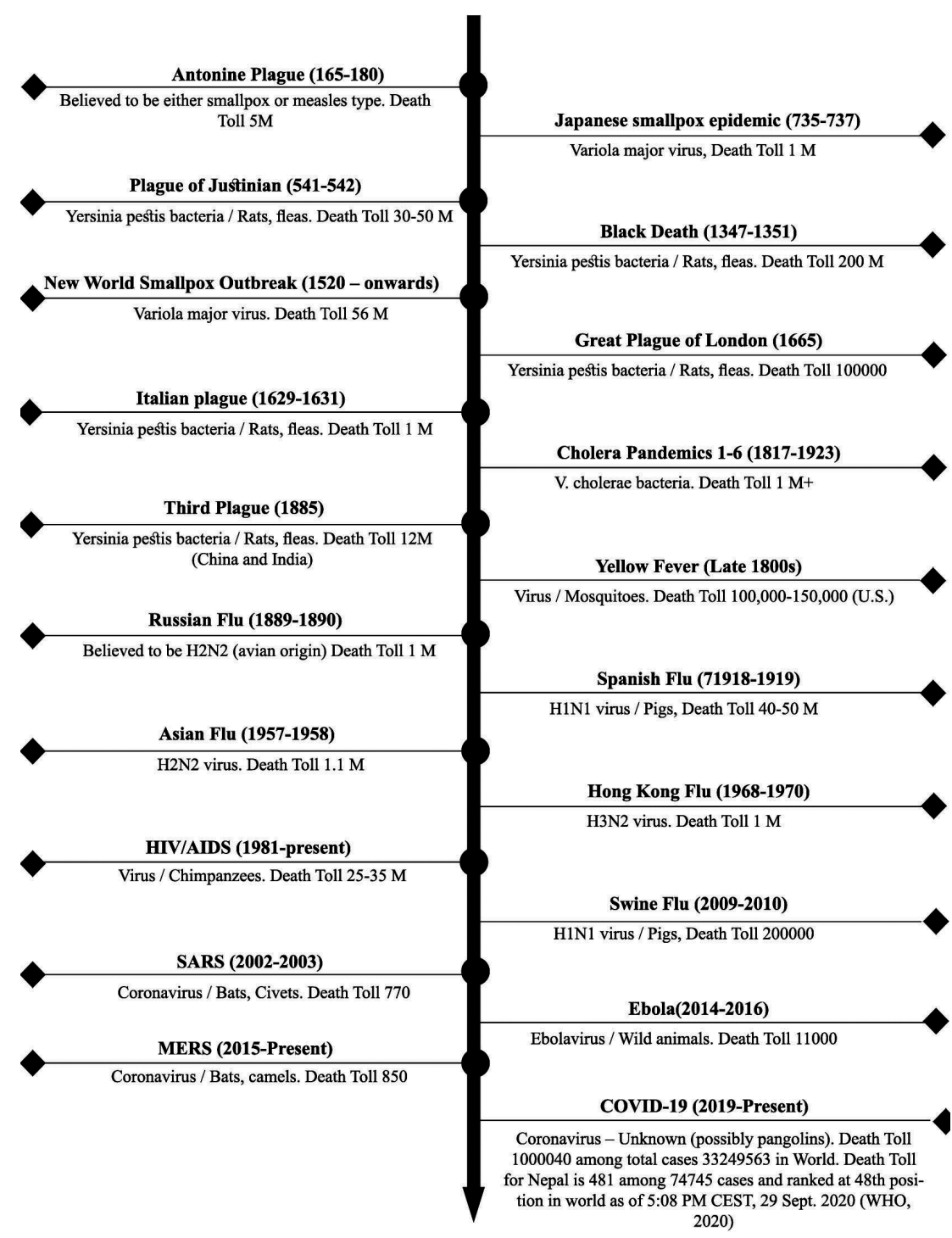

Source: LePan (2020); WHO, (2020)

Figure 1: Timeline of Major Epidemic in the World 
Spreading of communicable disease, practice to mange and control have long history however ways of management varies from time and space. Human kind has endured numerous miserable tragedies due to epidemics in the world. History tells that leprosy, plague and other infectious diseases were prevalent and Europe was escorted by such epidemics (Rothman, 2012). Some of them exterminate millions of people's lives mostly in the Europe. Since that time, study of the occurrence of illness, distribution, frequencies and determinants of disease taken as important aspect of human life. Timeline of major events in history of pandemics are presented as follows:

Throughout the history, human being has suffered by many infectious diseases continuously. John Hopkins University of Medicine (2020) stated that three flu pandemics are occurring every century and the chance of spreading and mass infection is increasing due to global connectivity. Figure 1 shows that major epidemics which have higher death toll with periods. However, losses due to infectious disease cannot be underestimated by other epidemics such as Antonine Plague, Small Pox, Yellow Fever, Spanish Flu, Swine Flu, Ebola and Severe Acute Respiratory Syndrome (SARS).

The term COVID-19 was first used by the World Health Organization (WHO) on 11 Feb., 2020 and it was emerged from Wuhan of China in the late December 2019. It is considered as a novel Corona virus-(SARS CoV-2) and WHO declared COVID-19 as pandemic on 11 March 2020 (Amgai et al., 2020; Bhandary et al., 2020; Wu et al., 2020). They claimed that the novel coronavirus is a single stranded RNA virus which is a zoonotic disease and has led to human infection predominantly through air droplets which is the seventh coronavirus known that infects humans (Zhu et al., 2020). This is not a new virus in this world which was first discovered in the 1930s (Amgain et al., 2020). Coronavirus causes mild sickness like the common cold to acute illness such as Middle East Respiratory Syndrome (MERS) and SARS (Panthy et al., 2020). According to WHO (2020), cough, fever, difficulty breathing, change of taste are the common symptoms of COVID-19.

Nepal is also at the forefront of the COVID-19 crisis like other countries as the first COVID-19 case was reported on 13 January 2020 from a 32 years old male who came from Wuhan, China on 9 January 2020. He was admitted to hospital with mild symptoms related to COVID-19 but the disease was not named as COVID-19 till that time (Sapkota et al., 2020; Bhandary et al, 2020). Though, Nepal formally announced the first case on 24 January, 2020 (Pun et al., 2020). After 3 months of the first case confirmation in Nepal, the second case was found on March 23 ${ }^{\text {rd }}, 2020$ in a 19 years old female who had come from France via Doha, Qatar (Bhandary et al., 2020). Thereafter, the nationwide lockdown was implemented to prevent form COVID-19 until 24 March 2020 to 21 July 2020 (Pradhan, 2020). Despites the government effort 
to stop COVID-19 spread in the community, positive cases are increasing day by day. Whereas 300 people died out of 47236 confirmed cases by 8 September 2020. Out of these confirmed cases, 30677 people (64.9\%) were fully recovered (MoHP, 2020). No effective and standard treatment of COVID-19 has been developed till today (Wu et al., 2020). Health related organizations including WHO are claiming that frequent handwashing with soap, social distancing and using masks plays an important role to stop its spreading which works as preventive measures.

Like other districts, Dhankuta district also suffering from the pandemic of COVID-19, among the 2144 PCR test, 45 are positive cases (4 females and 41 males) until 22 September, 2020 where no record of death (District Health Office, 2020). The various governmental and non-governmental organizations have been involving in the dissemination of health related awareness programmes through electronic, print and social media (Ahmed et al., 2020). Among these, public awareness about the pandemic of COVID-19 is also considered an important task in many countries, like Nepal. In Nepal, the three tiers governments (local, provincial and federal) have been playing a significant role against this pandemic through different sources- education, media, social media and so on. In this case, teachers can play an important role in the campaign of preventive measure of COVID-19. It is considered that their capacity has multiplier effect against the drive to pandemic measure through the mobilization of students. Their efforts can be very effective to reduce the number of COVID-19 infections and to minimize dispersal of such pandemic cases. Among them, university teachers are supposed to be intellectual people in terms of knowledge and understanding of the famine, epidemic, misery and viral diseases like COVID-19. However, Marahatta \& Paudel (2020) suggest that community engagement is required because only scientific community and health care workers would not sufficient to control the pandemic

COVID-19 pandemic exacerbated many problems at academic sectors along with agriculture, business, and labour work. It has compelled to change the way of life, work and business all over the world. Hence, this paper aims to analyze the case of teachers' knowledge and understanding about the COVID-19 and its impacts on their academic environment in Dhankuta Multiple Campus, eastern hills of Nepal.

Numerous studies are conducted in Nepal about the COVID-19 although there is a lack of study related to the investigation of knowledge as well as preventive practices of higher-level educators. COVID-19 may bring challenges in entire sectors however this study emphasis only on academic sectors. This study will be helpful to concerned agencies and authorities for guidance and policy making for management, preparation and tackle to pandemic. To understand pandemic like COVID-19, significantly helps to identify the people who are at risk, to mobilize resources, and to find out the best way to respond the disease for today and tomorrow. 


\section{Methods and Materials}

Study was carried out through web based cross sectional study design on 22-30 August 2020. Due to the unequal distribution of numbers by faculties and institutes, proportionate Stratified Random Sampling (SRS) method was applied to select respondents. Information was collected by sharing links of structured questionnaires through google form sharing via g-mail and Facebook messenger groups. Beside it, other necessary data was collected from the campus records. Questionnaire was validated through online pilot study on teachers at higher level education. Total sample size determination method was adopted from McClave and Sincich (2018) and the details steps are presented as follows:

Step 1: Initial estimate of sample size for simple random sampling (SRS) design

Where,

$$
n^{\prime}=\frac{1.96^{2} \times p(1-p)}{(\text { standard Error })^{2}}
$$

$\mathrm{n}^{\prime}=$ Intial Estimate of Sample Size

$1.96^{2}=\mathrm{z}$ Value at $95 \%$ Confidence level

$\mathrm{p}=$ Population Proportion

$q=1-p$

Suppose,

$\mathrm{p}=0.5$ and Standard Error $5 \%$ i.e. 0.05

$$
\begin{aligned}
\mathrm{n}^{\prime} & =\frac{\left[1.96^{2} \times 0.5 \times(1-0.5)\right]}{0.5^{2}} \\
& =384.16 \text { i.e. } 385
\end{aligned}
$$

\section{Step 2: Adjustment with Population Size}

Where,

$$
\mathrm{n}_{\text {srs }}=\frac{n^{\prime}}{\left[1+\left(n^{\prime} / N\right)\right]}
$$

$\mathrm{n}_{\mathrm{srs}}=$ Sample Size for Simple Random Sampling (SRS)

$\mathrm{N}=$ Total Number of Population

Suppose,

$$
\begin{aligned}
\mathrm{N}= & 58 \\
\mathrm{n}_{\text {srs }} & =\frac{385}{[1+(385 / 58]} \\
& =50.40632
\end{aligned}
$$




\section{Step 3: Adjustment of non-response rate to obtain desire sample size}

Desired sample size $=\frac{n_{\text {srs }}}{\text { Response Rate }}$

Suppose,

Non-response Rate $=1 \%$ i.e. 0.01

Response Rate $=(1-$ Non-response Rate $)$

$$
\begin{aligned}
& =(1-0.01) \\
& =0.99
\end{aligned}
$$

Desired Sample Size $=\frac{50.40632}{0.99}$

$$
=50.92 \text { i.e } 51
$$

With the adoption of the proportionate stratified random sampling method from Suwal, 2013, sample size was determined as follows:

\begin{tabular}{|c|c|c|c|c|c|c|c|c|}
\hline Domains, $h$ & $\begin{array}{l}\text { Total } \\
\text { No } \\
\left(M_{h}\right)\end{array}$ & $\begin{array}{c}\text { Proport } \\
\text { ion } \\
\left(W_{h}\right)\end{array}$ & $\begin{array}{c}\text { Sample } \\
\text { size } \\
\left(\mathbf{N}_{h}{ }^{e}\right)\end{array}$ & $\begin{array}{c}\text { Probab } \\
\text { ility } \\
\left(\mathrm{pr}_{\mathrm{h}}^{\mathrm{e})}\right.\end{array}$ & $\begin{array}{c}\text { sampl } \\
\text { ing rate } \\
\left(\mathrm{sr}_{\mathrm{h}}{ }^{\mathrm{e}}\right)\end{array}$ & $\begin{array}{c}\text { sample } \\
\text { size } \\
\left(\mathrm{N}_{\mathrm{h}}^{\mathrm{p}}\right)\end{array}$ & $\begin{array}{c}\text { Probab } \\
\text { ility } \\
\left(\mathrm{pr}_{\mathrm{h}} \mathrm{p}\right)\end{array}$ & $\begin{array}{c}\text { sampling } \\
\text { Rate } \\
\left(\mathrm{Sr}_{\mathrm{h}} \mathrm{p}\right)\end{array}$ \\
\hline Faculties & & & \multicolumn{3}{|c|}{ Equal sample size } & \multicolumn{3}{|c|}{ Proportionate allocation } \\
\hline Faculty (1) & $\begin{array}{l}\text { No } \\
\text { (2) }\end{array}$ & $\begin{array}{c}\text { Total/No } \\
\text { (3) }\end{array}$ & $(4)=51 /(1)$ & $(5)=(4) /(2)$ & $(6)=1 /(5)$ & $\begin{array}{c}(7)= \\
(3)^{* 56}\end{array}$ & $\begin{array}{l}(8)=(7) / \\
(2)\end{array}$ & $\begin{array}{c}(9)=1 / \\
(8)\end{array}$ \\
\hline Education & 28 & 0.4828 & 12.75 & 0.455357 & 2.20 & 25 & 0.879310 & 1.14 \\
\hline Humanities & 19 & 0.3276 & 12.75 & 0.671053 & 1.49 & 17 & 0.879310 & 1.14 \\
\hline Management & 5 & 0.0862 & 12.75 & 2.550000 & 0.39 & 4 & 0.879310 & 1.14 \\
\hline Science & 6 & 0.1034 & 12.75 & 2.125000 & 0.47 & 5 & 0.879310 & 1.14 \\
\hline Total & 58 & 1.0000 & 51 & 5.801410 & 4.55 & 51 & 3.517241 & 4.55 \\
\hline
\end{tabular}

Table 1: Sample Selection Process: Equal and Proportionate Allocation of Sample and Indicators of Sample Design

Source: Dhankuta Multiple Campus, 2020

Note: The actual no. of teachers is 60 at Dhankuta Multiple campus at present and authors of this article also involved in the same institution although these two respondents (authors) are excluded from sampling unit due to ethical consideration.

Study variables taken under this study were as follows;

1. Basic socio-demographic characteristics as age, sex, faculties, ethnicity

2. Knowledge about COVID-19

3. Preventive practices from COVID-19

4. Academic impact due to COVID-19 and

5. Adopted measures to overcome impact from COVID-19 
Quantitative research design was applied and descriptive data analysis was used with the support of SPSS V26 software. Literatures related to COVID-19 was searched on the database of the internet through sites such as Google Scholar, Crossref, ResearchGate. Informed consent was taken from all participants by asking to click on if you agree to provide answers related to your knowledge and adopting preventive measures on question form.

\section{Results and Discussion}

Brief background information of Dhankuta Multiple Campus and data obtained from study are presented according to the objectives and the nature of data. Three prominent issues as knowledge and understanding of teachers, preventive practices and opportunities and challenges in academic arena related to COVID-19 are discussed in this section.

\section{Dhankuta Multiple Campus: An Overview}

Initially, the name of Dhankuta Multiple Campus was Dhankuta College, which was established in 1955 (Baral, 2001; Subedi \& Joshi, 1997). In the beginning there was only an intermediate level (I.A.) under the Faculty of Humanities and Social Science and it was upgraded up to Bachelors Level (B.A.) in 1957 then Dhankuta College was renamed as Dhankuta Degree College. In 1973 when the National Education System Plan (NESP) was implemented, unfortunately the Bachelors level (B.A.) teaching program was closed. However, the Intermediate level (I.Ed.) teaching was started under the Faculty of Education in College in the same year then the name of this college changed into Dhankuta Multiple Campus (Bhattrai, 2061; Guragain, 2061. After that point, Bachelors (B.Ed) level teaching under the Faculty of Education was begun in 1977 for the first time. Bachelors level (B.A.) study was also re-started in 1981 under the Faculty of Humanities and Social Science (Bhattrai, 2061). Currently, this organization has four Faculties/Institutes: Education, Humanities, Management and Science and Technology. Similarly, the teaching level also upgraded to Master's level in Rural Development under the Faculty of Humanities and Social Science and Educational Planning and Management (EPM), Nepali, English and Health under the Faculty of Education. Master's Degree course in Management (MBS) is also running on this campus (TUTA, 2075). However, primary aim of this paper is to provide a level of knowledge about COVID-19 and prevention practices applied by teachers of this institution at the current pandemic situation, in which the country has been locked down frequently and the higher education sector is negatively influencing.

\section{Demographic characteristics of respondents}

Basic demographic features like age, sex and ethnicity are highly associated with understanding and knowledge level. To considering this, it is an important to 
depict the background demographic characters for further analysis. Respondents demographic details are as follows:

Table 2: Respondents by Age, Sex and Ethnicity by Faculty

\begin{tabular}{|c|c|c|c|c|c|c|c|c|c|c|c|c|c|}
\hline \multirow{3}{*}{ Faculties } & \multirow{2}{*}{\multicolumn{3}{|c|}{$\begin{array}{r}\text { Age } \\
\text { Men Age }\end{array}$}} & \multirow[b]{3}{*}{ S.D. } & & & \multicolumn{6}{|c|}{ Ethnicity } & \multirow[b]{3}{*}{ 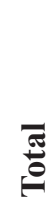 } \\
\hline & & & & & \multicolumn{2}{|c|}{ Total } & \multirow{2}{*}{ 竭 } & \multirow[b]{2}{*}{ 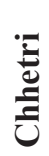 } & \multirow[b]{2}{*}{ ž } & \multirow[b]{2}{*}{ 音 } & \multirow[b]{2}{*}{$\ddot{\ddot{\approx}}$} & \multirow[b]{2}{*}{ 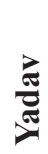 } & \\
\hline & $\mathbf{M}$ & $\mathbf{F}$ & Total & & $\mathbf{M}$ & $\mathbf{F}$ & & & & & & & \\
\hline Education & 45 & 36 & 44 & 8 & 22 & 3 & 14 & 4 & 3 & 1 & 3 & 0 & 25 \\
\hline Humanities & 45 & 40 & 44 & 7 & 15 & 2 & 13 & 1 & 2 & 0 & 1 & 0 & 17 \\
\hline Management & 38 & 0 & 38 & 4 & 4 & 0 & 4 & 0 & 0 & 0 & 0 & 0 & 4 \\
\hline Science & 42 & 0 & 42 & 5 & 5 & 0 & 0 & 0 & 1 & 1 & 0 & 3 & 5 \\
\hline \multicolumn{5}{|c|}{ Total } & 46 & 5 & 31 & 5 & 6 & 2 & 4 & 3 & 51 \\
\hline
\end{tabular}

Source: Online Survey, 2020

$(\mathrm{M}=$ Male, $\mathrm{F}=$ Female, S.D. $=$ Standard Deviation $)$

Out of total $(\mathrm{N}=51)$ respondents, nearly $90 \%$ were male and remaining were female. In this campus, altogether females are only five in numbers although they all were selected through the random sampling process. Similarly, $60.7 \%$ teachers are were Brahmin, 11.7 from Newar, 9.6\% from Chhetri, 7.9 form Rai, 5.8\% from Yadav and $3.9 \%$ are from Limbu ethnic group out of total teachers. Though, gender and ethnicity are not the focus area of this research. The average mean age of the respondents seemed 44 years in both Education and Humanities Faculties whereas 38 and 42 years in Management and Science faculties respectively. Although, the mean age of female respondents seemed lower than male in both Education and Humanities faculties.

\section{Information Source}

Awareness and level of knowledge depends upon access on information sources. At present, sources of information are diffused by technological innovation. Among which Radio/TV, Social media, friends/relatives, family members and others (newspaper, websites) are mainly taken as a source of information for this study. The details sources of information as follows;

Table 3: Source of Information About COVID-19 by Faculty

\begin{tabular}{lccccc}
\hline Faculties & Radio/TV & $\begin{array}{c}\text { Social } \\
\text { Media }\end{array}$ & Friends/Relatives & $\begin{array}{c}\text { Family } \\
\text { Members }\end{array}$ & Others \\
\hline Education & $22(47.8)$ & $24(52.2)$ & $16(53.3)$ & $13(50.0)$ & $1(33.3)$ \\
Humanities & $15(32.6)$ & $13(28.3)$ & $7(23.3)$ & $7(26.9)$ & $2(66.7)$ \\
Management & $4(8.7)$ & $4(8.7)$ & $3(10)$ & $3(11.5)$ & $0(0)$ \\
Science & $5(10.9)$ & $5(10.9)$ & $4(13.3)$ & $3(11.5)$ & $0(0)$ \\
\hline Total & $\mathbf{4 6}$ & $\mathbf{4 6}$ & $\mathbf{3 0}$ & $\mathbf{2 6}$ & $\mathbf{3}$ \\
\hline
\end{tabular}

Source: Online Survey, 2020

(No. in parenthesis indicates percentage) 
Table 3 indicates that Radio/TV (46) and Social media (46) are being the major source among teachers in terms of gaining information. Whereas friends and relatives (30) hold second position as a source of information. Similarly, around half of the information was gained from family members (26) about COVID-19 and contribution of other sources (3) like newspapers and websites seemed negligible. Among those who have selected Radio/TV as source of information, $47.8 \%$ were from Education, $32.6 \%$ from Humanities and $8.7 \%, 10.9 \%$ were from Management and Science respectively. In comparison to Faculty within social media, $52.4 \%$ teachers were involved in Education, $28.3 \%$ were in Humanities and the rest number of teachers were involved in Management and Science. Friends/relatives seems the next vital source of information, in which $53.3 \%, 23.3 \%, 10 \%$ and $13.3 \%$ were involved in Education, Humanities, Management and Science respectively. Around $50 \%$ of respondents got information from family members and contribution from other sources is around $6 \%$. In conclusion, Radio/TV and social media are becoming vital sources of information to raise awareness in pandemic situations.

\section{Understanding about COVID-19}

Understanding depends upon types of information, used language and access to sources of information which helps to transform behavior of people. Knowledge about symptoms and mode of transmission plays significant roles for the management of pandemics like COVID.

Table 4: Knowledge of Symptoms and Mode of Transmission About COVID-19

\begin{tabular}{lcccc}
\hline \multicolumn{1}{c}{ Description } & Ture & Percent & False & Percent \\
\hline Symptoms & & & & \\
High Fever & 50 & 98 & 1 & 2 \\
Cough & 42 & 82.4 & 9 & 17.6 \\
Running Nose & 42 & 82.4 & 9 & 17.6 \\
Breathing Difficulty & 50 & 98 & 1 & 2 \\
Fatigue/Weakness & 41 & 80.4 & 10 & 19.6 \\
Taste change & 7 & 13.7 & 44 & 86.3 \\
Transmission & & & & \\
Direct Touch & 44 & 86.3 & 7 & 13.7 \\
Through Droplets & 44 & 86.3 & 7 & 13.7 \\
Through Air & 27 & 52.9 & 24 & 47.1 \\
Surface & 5 & 9.8 & 46 & 90.2 \\
\hline
\end{tabular}

Overall Mean knowledge score $=6.90$

Source: Online Survey, 2020 
Symptoms and mode of transmission related to COVID-19 were taken as declared by WHO in this study. Among major symptoms of COVID-19, $98 \%$ respondents provided true answers for high fever and breathing difficulty. For cough and running nose, $82.4 \%$ provided true score whereas $80.4 \%, 13.7 \%$ scored in true for fatigue/weakness and taste change respectively.

In terms of mode of transmission, $86.3 \%$ reported true answers for direct touch and through droplets transmission. Similarly, $52.9 \%$ and $9.8 \%$ gave true scores for transmission by air and surface. By considering both these knowledge related terms i.e., symptoms and mode of transmission, the obtained knowledge mean score is 6.9 out of 10. It shows the average knowledge level of University teachers involved in Dhankuta Multiple Campus is above average.

\section{Ranking of vulnerable places}

Each and every place does not hold an equal chance of spreading pandemic. Comparatively public places hold higher chances of spreading than others. In this context, ranking as per the knowledge of community people can be beneficial to the management of COVID-19. Ranking by respondents to the vulnerable place is presented as follows:

Table 5: Ranking of vulnerable place for COVID-19

\begin{tabular}{|c|c|c|c|c|c|c|}
\hline \multirow{2}{*}{$\begin{array}{c}\text { Vulnerable } \\
\text { Place } \\
\end{array}$} & \multirow[b]{2}{*}{ Low } & \multicolumn{2}{|l|}{ Below } & \multicolumn{2}{|l|}{ Above } & \multirow{2}{*}{$\begin{array}{l}\text { Mean } \\
\text { Value } \\
\end{array}$} \\
\hline & & Average & Average & Average & High & \\
\hline Hospital & $13(25.5)$ & $3(5.9)$ & $6(11.8)$ & $3(5.9)$ & $26(51.0)$ & 38.3 \\
\hline Schools & $10(19.6)$ & $6(11.8)$ & $5(9.8)$ & $15(29.4)$ & $15(29.4)$ & 41.2 \\
\hline Hotels & $7(13.7)$ & 7 (13.7) & $13(25.5)$ & $14(27.5)$ & $10(19.6)$ & 44.1 \\
\hline Marketing Area & $7(13.7)$ & $12(12)$ & $10(19.6)$ & $5(9.8)$ & $17(33.3)$ & 44.1 \\
\hline $\begin{array}{l}\text { Governmental } \\
\text { Offices }\end{array}$ & $16(31.4)$ & $7(13.7)$ & $11(21.6)$ & $5(9.8)$ & $12(23.5)$ & 39.2 \\
\hline
\end{tabular}

Source: Online Survey, 2020

(No. in parenthesis indicates percentage)

According to the rank given by teachers on the basis of risk, hospital is ranked as high-risk areas by 26 (51\%) respondents out of 51 whereas one fourth of them ranked hospital as a low risk area. School is considered as a high risk and above average risk area equally by $15(29.4 \%)$ respondents. Only $10(19.6 \%)$ respondents ranked hotel as a high-risk area and nearly half of the respondents ranked above average and high-risk areas. Around one third of the respondents (17) ranked marketing areas as highly vulnerable places. But governmental offices are not taken as high-risk areas as other vulnerable places by respondents. In summary, respondents have ranked Hotels and Marketing Areas as the highest vulnerable areas than other places on the basis of 
calculated mean score which is contrasted to number value. Causes behind ranking schools as a second position because they are used as quarantine and isolation areas by the government.

\section{Ranking of preventive methods}

Ranking measures respondent's ideas, value, information and knowledge about related areas. Importance of preventive methods ranking provided by respondents may be very useful to manage COVID-19 like pandemics for the concerned organization and authorities. On the basis of existing knowledge for the prevention of COVID-19 developed by different national and international health organizations are ranked by respondents as follows:

Table 6: Ranking of Preventive Methods on the Basis of Importance by Respondents

\begin{tabular}{lccccccc}
\hline \multirow{2}{l}{ Methods of Prevention } & $\begin{array}{c}\text { Not } \\
\text { Important }\end{array}$ & $\begin{array}{c}\text { slightly } \\
\text { Important }\end{array}$ & $\begin{array}{c}\text { Moderately } \\
\text { Important }\end{array}$ & $\begin{array}{c}\text { Very } \\
\text { Important }\end{array}$ & $\begin{array}{c}\text { Extremely } \\
\text { Important }\end{array}$ & $\begin{array}{c}\text { Mean } \\
\text { Score }\end{array}$ \\
\hline Using Mask & No. (\%) & $8(15.7)$ & $2(3.9)$ & $3(5.9)$ & $10(19.6)$ & $28(54.9)$ & 43.16 \\
Using Sanitizer & No. (\%) & $6(11.8)$ & $8(15.7)$ & $3(5.9)$ & $8(15.7)$ & $26(51.0)$ & 45.12 \\
Stay at Home & No. (\%) & $13(25.5)$ & $1(2)$ & $3(5.9)$ & $5(9.8)$ & $29(56.8)$ & 38.25 \\
Keep Quarantine & No. (\%) & $5(9.8)$ & $2(3.9)$ & $5(9.8)$ & $6(11.8)$ & $33(64.7)$ & 46.1 \\
Medicinal Plants & No. (\%) & $7(13.7)$ & $8(15.7)$ & $5(9.8)$ & $7(13.7)$ & $24(47.1)$ & 44.14 \\
Stop Gathering & No. (\%) & $9(17.6)$ & $1(2)$ & $5(9.8)$ & $8(15.7)$ & $28(54.9)$ & 42.18 \\
Follow Lockdown & No. (\%) & $7(13.7)$ & $5(9.8)$ & $5(9.8)$ & $3(5.9)$ & $31(60.8)$ & 44.14 \\
Take Medicine & No. (\%) & $15(29.4)$ & $3(5.9)$ & $1(2)$ & $5(9.8)$ & $27(52.9)$ & 36.29 \\
\hline
\end{tabular}

Source: Online Survey, 2020

(No. in parenthesis indicates percentage)

Ranking of preventive methods by importance provided through respondents is presented in the above table. Among the methods of prevention, more than two thirds of respondents ranked using masks, using sanitizer, stop gathering and keeping in quarantine are the most important methods to prevent form COVID-19. Taking medicinal plants, immune booster medicine is given less importance by respondents. Similar types of conclusions can be drawn from the value of mean scores.

\section{Preventive practices}

Preventive practice supports to break down the route of disease transmission and is very important to stop spreading any epidemic or any communicable disease, which is guided by people's level of knowledge, beliefs, values and awareness. Preventive practices are highly associated with basic hygiene practice for most diseases as well as COVID-19. Study of adopted practices by people are necessary to find out prevalence and probability of prevalence for future. 
Table 7: Preventive Practices Adopted by Respondents

\begin{tabular}{lllll}
\hline \multicolumn{1}{c}{ Practices } & Yes & Percent & No & Percent \\
\hline Using Masks & 49 & 96.1 & 2 & 3.9 \\
Washing Hands/Sanitizer & 48 & 94.1 & 3 & 5.9 \\
Staying at Home & 46 & 90.2 & 5 & 9.8 \\
Using Medicinal Plants & 37 & 72.5 & 14 & 27.5 \\
Stop Gathering & 41 & 80.4 & 10 & 19.6 \\
Following lockdown & 42 & 82.4 & 9 & 17.6 \\
taking Medicine & 30 & 58.8 & 21 & 41.2 \\
Changing Food Pattern & 37 & 72.5 & 14 & 27.5 \\
\hline
\end{tabular}

Source: Online Survey, 2020

Majority of the respondents are preventing themselves by using masks while going outside, regular hand washing/sanitizing and staying at home $(96.1 \%, 94.1$ $\%$ and $90.2 \%$ respectively).Moreover, they are also taking medicinal plants such as Gurjo (Tinospora Sinensis), lemon and Turmeric, stop gathering, follow lock down and taking medicine to boost up immunity which shared $72.5 \%, 80.4 \%, 82.4 \%$ and $58.8 \%$ respectively. Similarly, more than two thirds respondents have changed their food pattern after the outbreak of COVID-19. In terms of food practice, they are taking plenty of hot water, balanced diet as their information, so the food pattern has been changed. Majority of respondents are taking the practice of using masks, hand washing with soap/sanitizing, and staying at home as significant preventive practices from COVID-19. The overall mean practice score was 6.4 which indicates that the teachers of DMC are supporting to stop the spreading pandemic to the community.

\section{Academic Challenges, Management and Opportunities}

Problem of lockdown is being faced by most countries of the world while slowing down the spread of COVID-19. Although lockdown is helpful to stop the additional spread of COVID however, it has created numerous problems in most of the social sectors. Government and other national and international organizations are taking effort to manage this problem as well as practices adopted by family and individuals. Out of these, the academic sector is not an exception. In the case of the academic sector, it creates both problems/challenges as well as opportunities. The academic problems faced by respondents and their effort to overcome these problems have been presented as follows: 
Table 8: Academic challenges, Its Management and Opportunities

\begin{tabular}{lllll}
\hline Description & Yes & Percent & No & Percent \\
\hline $\begin{array}{l}\text { Difficulties Facing } \\
\text { Types of Difficulty }\end{array}$ & 48 & 94.1 & 3 & 5.9 \\
Course Delay & 45 & 88.2 & 6 & 11.8 \\
Library Access & 37 & 72.5 & 14 & 27.5 \\
Academic Activities & 42 & 82.4 & 9 & 17.6 \\
Others & 8 & 15.7 & 43 & 84.3 \\
Difficulties Overcome & & & & \\
Taking Online Class & 37 & 72.5 & 14 & 27.5 \\
Using E-Library & 23 & 45.1 & 28 & 54.9 \\
Working from Home & 37 & 72.5 & 14 & 27.5 \\
Others & 2 & 3.9 & 49 & 96.1 \\
Academic Opportunities Received & 36 & 70.6 & 15 & 29.4 \\
Types of Opportunities & & & & \\
ICT Learning & 28 & 54.9 & 23 & 45.1 \\
Webinar Participation & 30 & 58.8 & 21 & 41.2 \\
Time for read and Write & 26 & 51.0 & 25 & 49.0 \\
Access on useful resource & 22 & 43.1 & 29 & 56.9 \\
\hline
\end{tabular}

Source: Online Survey, 2020

Table 8 presents information about academic challenges created by COVID-19, challenges reduction strategy practices and related academic opportunities received by respondents. Academic challenges were enlisted as course delay, library access and academic activities. Majority $48(94.1 \%)$ of the teachers have faced academic difficulties during this period. Among the academic challenges, course delay (88.2 $\%$ ) is outnumber than others followed by academic activities such as reading, writing and conducting research works $(82.4 \%)$. To reduce the above-mentioned academic challenges, they have adopted taking online classes (72.5\%), using E-library (45.1 $\%$ ), working from home (72.5\%). Beside these challenges faced by teachers they have received some academic opportunities too. Among the total respondents, 36 (70.6\%) reported that they received some types of academic opportunity during this survey period. Opportunity of participation in national and international webinar received by $58.8 \%$ from majority of the respondents. Opportunity of ICT learning, sufficient time for reading and writing and access to useful resources received by $54.9 \%, 51.0 \%$ and $43.1 \%$ respectively. 


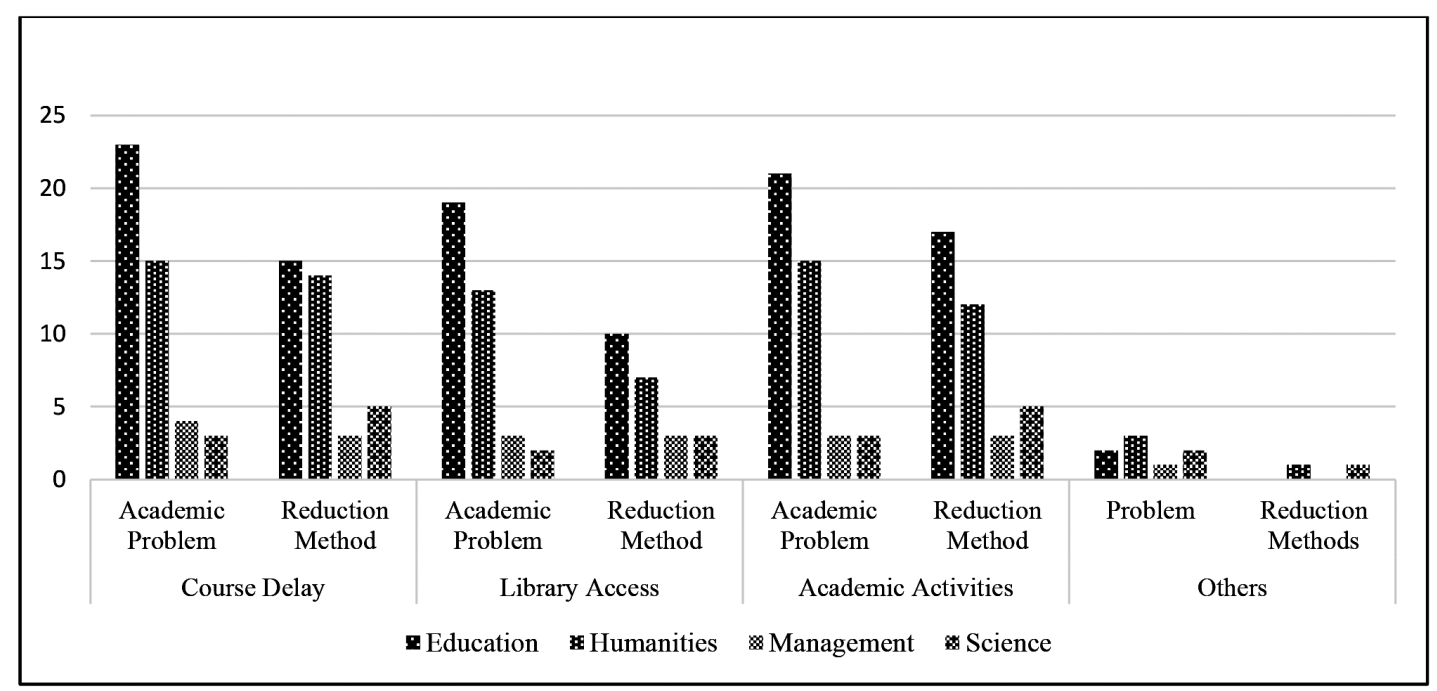

Figure 2: Facing Problems and Reduction Methods

Facing academic problems by Faculties are presented by the above figure. Among the 45 respondents who have reported course delay problems, 23 were from the Faculty of Education, 15, 4 and 3 were from Humanities, Management and Institute of Science and Technology respectively. Out of 37 respondents who have reported a problem regarding access to the library, 19 respondents were involved in the Faculty of Education, 13 from Humanities, 3 from Management and 2 from Science and Technology. Similarly, in academic activities 21 (Education), 15 (Humanities), 3 (Management) and 3 (Science) out of 42 have reported problems. Simultaneously, to overcome the challenges respondents have adopted various approaches among them 15 from Education, 14 from Humanities and 3 from Management and 5 from Science taking online classes. In the Context of E-library use 10 were from Education, 7 from Humanities, 3 from Management and 3 from Science. Similarly, 17, 12, 3 and 5 respondents were engaged in academic work from house.

Table 9: Received Opportunities During Lockdown Period

\begin{tabular}{|c|c|c|c|c|c|c|c|c|}
\hline \multirow[t]{2}{*}{ Faculties } & \multicolumn{2}{|c|}{$\begin{array}{c}\text { ICT } \\
\text { Learning }\end{array}$} & \multicolumn{2}{|c|}{$\begin{array}{c}\text { Webinar } \\
\text { Participation }\end{array}$} & \multicolumn{2}{|c|}{$\begin{array}{l}\text { Time for Read } \\
\text { and Write }\end{array}$} & \multicolumn{2}{|c|}{$\begin{array}{c}\text { Access on } \\
\text { Sources }\end{array}$} \\
\hline & No & Yes & No & Yes & No & Yes & No & Yes \\
\hline Education & 13 & 12 & 9 & 16 & 12 & 13 & 14 & 11 \\
\hline Humanities & 7 & 10 & 10 & 7 & 10 & 7 & 11 & 6 \\
\hline Management & 1 & 3 & 1 & 3 & 1 & 3 & 2 & 2 \\
\hline Science & 2 & 3 & 1 & 4 & 2 & 3 & 2 & 3 \\
\hline
\end{tabular}

Source: Online Survey, 2020 
The Table above shows that nearly half of the respondents received different types of opportunities during this time. Among them, the participation of national and international webinar in order to enhance their knowledge is higher than other followed by ICT learning. In terms of ICT learning, $75 \%$ respondents were involved from Management whereas only $48 \%$ respondents received from the Faculty of Education. The respondents of Science and Technology reported that $80 \%$ have participated in different national and international webinars. On the contrary, only $41 \%$ respondents were from Humanities in webinars. The respondents from Management faculty seemed higher to get sufficient time for reading and writing in comparison to the faculty of Humanities. In the case of access to useful academic resources, the respondents of science are outnumbered than others followed by the respondents from Management.

\section{Teacher's Experience and Perceptions on COVID-19 Situation}

Majority of teachers expressed their view that they have felt difficulty in initial period of lockdown. It disrupted academic activities nonetheless they adopted with this situation and taking their classes through online platform. They are also enhancing their skills and knowledge through online platforms. Experiences and perceptions on COVID-19 situation by a teacher is presented representatively as follows:

Initially, I was panic from this dreadful situation by COVID-19, which disturbed most of the sectors including my classes. I was in dilemma because differ types of information were providing through communication means. There was uncertainty about the situation and lockdown. I was hearing and bearing lockdown for the first time but after some months I became used to living with lockdown. I started to use online platform to continue my academic activities such as zoom meetings, google class, Microsoft teams. I surprised after using these wonderful platforms as new way of techno-learning as alternative of conventional teaching learning activities. Now, I am giving continuity to my assigned classes as well as getting opportunities of virtual learning through online trainings and webinars. Really, I am happy to get these opportunities in this wicked situation which will be helpful to deliver knowledge in days to come. Now, I have no any difficulty to take classes assigned by department however the participation of students are ups and downs. (A teacher, 49 Years)

\section{Conclusion}

This study shows that most of the University teachers get information about the symptoms and transmission mode of COVID-19 from Radio/TV and Social media. It indicates that Radio/TV and Social media are the effective medium of information dissemination at the community level in this case. Teachers are perceived that high fever and breathing difficulty are major symptoms and it transmits through direct touch 
and droplets. They believe that using masks, handwash with soap/using sanitizer and stay at home are the major methods to prevent from COVID-19 pandemic. Similarly, they prioritize the market place and hotels as highly vulnerable places in terms of COVID-19 transmission. Follow the lockdown and keep quarantine to those people who come from outside than the present location as appropriate ways to prevent from COVID-19. Delay in course completion and access to visit the conventional library are the major challenges facing by teachers during lockdown. Whereas, they are involving into an online class, using e-library and perform academic activities from home are the actions taken by teachers to overcome these challenges. So, the teaching learning methods in University level is changing and teachers are enhancing their capacity by participating on different national and international webinars. Therefore, this pandemic and lockdown is creating the next positive window of opportunities in academia.

\section{References}

Ahmed, H., Ahmed, A., \& Saeed, M. A. (2020). Knowledge, attitude and practices (KAP) regarding the prevention against COVID-19 infection at the outset of outbreak in Pakistan amongst smart phone users. Biomedica, 36(COVID19-S2), 267-273. https://www.researchgate.net/publication/342303308

Amgain, K., Neupane, S., Panthi, L., \& Thapaliya, P. (2020). Myths versus Truths regarding the Novel Coronavirus Disease (COVID-2019) Outbreak. Journal of Karnali Academy of Health Sciences, 3(1), 1-6. https://doi.org/10.3126/jkahs. v3i1.28367

Baral, T. (2001). History of Dhankuta Multiple Campus. Chintan-Dhara. Dhankuta: Nepal Professors Association, Campus Unit, Dhankuta Multiple Campus, Dhankuta, 9, 80-82.

Bhandary, S., Shrestha, S. L., Khatiwada, R. P., Shah, D. N., Munankarmi, N. N., Banjara, M. R., Thapa-Parajuli, R., Manandhar, K. Das, Adhikari, R., \& Tuladhar, R. (2020). Trend analysis, modelling and impact assessment of COVID-19 in Nepal. MedRxiv, july, 1-22, https://doi.org/10.1101/2020.05.29.20117390

Bhattrai, G.B. (2061 B.S.). Premises of Educational Development in Dhankuta Multiple Campus (Saishik Bikasko Seroferoma Dhankuta Bahumukhi Campus). Chintan-Dhara (Golden Jubilee Special). Dhankuta: Tribhuvan University Teacher`s Association, Campus Unit, Dhankuta Multiple Campus, Dhankuta, $11,49-52$.

District Health Office (2020, September 22). Situation Report of Dhankuta district about COVID-19. 
Guragain, Y.P. (2061 B.S.). Nepalko Bartaman Saishik Sthithitima Dhankuta Bahumukhi Campusko Yogdan (Contribution of Dhankuta Multiple Campus for Present Nepalese Educational Status). Chintan-Dhara (Golden Jubilee Special). Tribhuvan University Teacher`s Association, Campus Unit, Dhankuta Multiple Campus, Dhankuta, 11,63-65.

Joha Hopkins University and Medicine (2020). What else is important to know about pandemics. Retrieved September 09, 2020, form https://coronavirus.jhu.edu/ covid-19-basics / understanding / covid-19 / module - 4 - epidemiology - understanding - the - spread - of - covid -19\#/ lessons/nKZ5tdYIjKNZUC8t7EW9opyeBfxLIdPK

LePan, N. (2020, March 14). Visualizing the History of Pandemics. Visual Capitalist, https:/www.visualcapitalist.com/history-of-pandemics-deadliest/

Marahatta, S. B., \& Paudel, S. (2020). Tackling COVID-19 in Nepal: Opportunities and challenges, Journal of Karnali Academy of Health Science, 3(COVID 19 Special Issue), 1-12.https://doi.org/10.3126/jkahs.v3i0.29231

McClave, J.T. \& Sincich, T. (2018). Statistics (13 ${ }^{\text {th }}$ Ed.) UK : Pearson Education Limited, Ministry of Health and Population. COVID-19 Response. Web Portal Retrieved September 08, 2020, from https://covid19.mohp.gov.np.

Panthy, L., Panthi, J., Amgain, K., Thapaliya, P., \& Laar, J. Van. (2020). COVID-19 in Nepal : Scarcity of Personal Protective Equipment ( PPE) and its COVID-19 in Nepal: Scarcity of Personal Protective Equipment ( PPE) and its Alternative. Europasian Journal of Medical Sciences, 2 (1), 74-78. https://doi. org/10.46405/ejms.v2i1.47

Pradhan, T.R. (2020, July 22). Government decided to lift the four-monthslong Coronavirus lockdown, but with conditions. The Kathmandu Post. https://kathmandupost.com/national/2020/07/21/government-decides-to-liftthe-four-month-long-coronavirus-lockdown-but-with-conditions

Pun, S.B., Mandal, S., Bhandari, L., Jha, S., Rajbhandari, S., Mishra, A.K., Chalise, B.S., \& Shah, R. (2020). Understanding Covid-19 in Nepal. JNepal Health Res Counc 2020 Jan-Mar; 18(46):126-127. https://doi.org/10.33314/jnhrc. v18i1.2629

Rothman, K. (2012). Epidemiology: An Introduction (2n ${ }^{\text {nd }}$ edn.). Oxford University Press.

Sapkota, K., Dangal, G., Koirala, M., Sapkota, K., Poudel, A., \& Dhital, S. R. (2020). Strategies for prevention and control of COVID-19 in Nepal. Journal of Patan 
Academy of Health Sciences, 7(1), 85-88. https://doi.org/10.3126/jpahs. v7i1.28879

Subedi, B.P. \& Joshi, B. (1997). About Geography in Nepal: An Outline for Discussion. Social Science in Nepal: Some Thoughts and Search for Direction. In Khatry, P.K. (Eds.). Kathmandu: Center for Nepal and Asian Studies, 99-112.

Suwal, B.R. (2013). A Note on Sample Design. The Economic Journal of Nepal. Central Department of Economics, Trbhuvan University, Nepal, 36 (1 \& 2) 141153

Tribhuvan University Teachers Association (2075 B.S.). Introduction of Dhankuta Multiple Campus, Dhankuta.

Wu, Y. C., Chen, C. S., \& Chan, Y. J. (2020). The outbreak of COVID-19: An overview. Journal of the Chinese Medical Association, 83(3), 217-220. https://doi. org/10.1097/JCMA.0000000000000270

World Health Organization(2020). Retrieved September 09, 2020, form https://covid19. who.int/

Zhu, N., Zhang, D., Wang, W., Li, X., Yang, B., Song, J., Zhao, X., Huang, B., Shi, W., Lu, R., Niu, P., Zhan, F., Ma, X., Wang, D., Xu, W., Wu, G., Gao, G. F., \& Tan, W. (2020). A novel coronavirus from patients with pneumonia in China, 2019. New England Journal of Medicine, 382(8), 727-733. https://doi. org/10.1056/NEJMoa2001017 